\title{
Original Artc
}

\section{Diagnostic Role of Fine Needle Aspiration Cytology in the Breast Lump With its Correlation with Histopathology}

\author{
Hazara Khatun', Suraiya Enam ${ }^{2}$, Maleeha Hussain ${ }^{3}$, Monowara Begum ${ }^{4}$
}

\begin{abstract}
This study was carried out to evaluate the accuracy of FNAC and its role in palpable breast lumps for the early surgical management in outdoor and indoor patients of Dhaka Medical College during the period of January to December 2000. FNAC was performed on 310 patients who presented with palpable breast fumps. Histopathology was available in $122 \mathrm{cases}$, among which cytologically diagnosed benign cases were 106 proved so histologically in 105 (99.05\%) cases but catagorized correctly in 99 cases. There was false negative diagnosis in one case.

All 14 cases diagnosed as malignant in cytological examination were confirmed as such histologically. Two cases reported as suspicious for malignancy in cytological diagnosis, was proved malignant histologically. False positive diagnosis was made in one case. The accuracy of FNAC in the diagnosis of breast lump is quite satisfactory and can be compared with histopathological diagnosis.
\end{abstract}

TAJ 2001; $14(2) ; 65-69$

\section{Introduction}

Fine Needle Aspiration Cytology (FNAC) has become an important diagnostic tool for the pathological services in the developed countries. Of the superficial organs, the common organs. which are diagnosed frequently by FNAC, are thyroid and breast. Along with superficial masses, gradually FNAC is also being performed in deepseated lesions under the guidance of ultrasonography or computed tomography.

FNA cytology for the diagnosis of palpable breast masses was introduced first by Martine and Stewart ${ }^{2}$ and later by Godwin? ${ }^{3}$. It has been regularly performed on breast masses at Shands Hospital at the University of Florida since $1982^{4}$. In 1984 Wanebo et $\mathrm{al}^{5}$, suggested fine needle aspiration in lieu of open surgical biopsies for the diagnosis of breast cancers.

In recent years, fine needle aspiration cytology has gained popularity as a procedure for diagnosing breast lumps including cancers and numerous authors have reported their experiences in $\mathrm{FNAC}^{6-7}$.

The breast lump is a problem of menarche and menopause. The high accuracy and cost effectiveness of FNAC have been reported for

I Assstant Prolessor, Department of Hislopathology, Ra,shaht Macical College, Ra|shai-6000, Bangladesh.

- Trainee, Rajshari Medical College, Rajsvai-6000. Bangladesh.

¿Assistant Prolessor, Depariment ol Histopathology, Rajshahi Madical Colege, Rajshai-6000, Bangladesh.

i Junior Consultant. Department of Gynaecology and Obstetrics, Rajsnahi Medicai College, Rajsharajo00, Bangladesh 
identifying carcinoma in a clinically suspicious palpable lesions of breast, ${ }^{\text {A }}$ It has largely replaced excisional breast biopsy in the recent years. The procedure can be performed during an office visit without anaesthesia, thus eliminating the cost of outpatient surgery. It also allows discussion with the patient of various treatment plans for malignant masses on the same visit ${ }^{\circ}$. Recurrence of breast lesion is also detected by this procedure and surgery can be avoided in many cases. The present study was carried out -

1. To evaluate the accuracy of FNAC and its correlation with histopathology.

2. To evaluate the role of FNAC for the early surgical management of palpable breast lesions.

\section{Materials and Method}

The study was done at the Deparment of Pathology in Dhaka Medical College during the period from January to December 2000 on both outdoor and indoor patients. The female patients presented with breast lump were selected for the study. Fine needle aspiration cytology was performed on 310 cases that presented with palpable breast lumps. The clinical history was taken from all patients following a checklist. Physical examination was done to determine the size, location, consistency, and fixity to chest wall, nipple retraction, discharge and regional lymph node involvement.

Fine needle aspiration was done in a separate, well-illuminated room of the pathology department. The patient was placed in a comfortable position, usually lying on her back without premedication, Under aseptic precaution, percutaneous aspiration of each mass was performed by a pathologist to obtain the closed specimen by means of 20 -gauge needle attached to 10-ml syringe. The content of the needle was expressed on to the plane glass slides and rapidly smeared. The smeared slides were promptly dropped into $95 \%$ ethyl alcohol for fixation and kept for 30 minutes. It was stained by $\mathrm{H} \& \mathrm{E}$ method. The prepared slides were examined under light microscope.

\section{Results}

Three hundred ten cases presented with breast lumps during the study period whose ages ranged from II to 80 years and lump size ranged from 1 to $10 \mathrm{~cm}$ with a mean $2.4 \mathrm{~cm}$. Their cytological diagnosis is shown in table $\mathrm{I}$.

Table II shows the cytological and histopathological diagnosis of 122 cases.

Out of 76 cases of cytologically diagnosed fibroadenoma, 2 cases were diagnosed histopathologically as fibrocystic disease and one case as benign phyllodes tumour. Out of 23 case of FCD, two cases were diagnosed as fibro-adenoma by histopathology. Mild atypia with fibrocystic disease diagnosed as malignant. One cytologically unsatisfactory smear was diagnosed histopathologically as FCD. Out of 106 cytologically diagnosed benign cases, correctly categorized benign cases were 99 , False negative diagnosis was made in one case. There were two cases reported as suspicious for malignancy, one was diagnosed as malignant and other was FCD on histopathology.

Table III shows the age distribution of benign and malignant cases that were proved histopathologically.

In the present series incidence of malignancy is high in $41-50$ years age group. Fibroadenoma and fibrocystic diseases were seen more commonly in 21-30 yrs. \& $31-40$ yrs. age groups respectively. There were two cases of inflammatory lesions; one of which was abscess and another was chronic granulomatous inflammation. One case diagnosed as old haemorrhage with a history of trauma about 15 days back. One case was diagnosed as galactocoele. A case of duct papilloma was noted at $4 \mathrm{I}-50$ yrs. age group. 
Table I: Cytological diagnosis $(n=310)$

\begin{tabular}{cccc}
\hline $\begin{array}{c}\text { Positive for } \\
\text { malignancy }\end{array}$ & Negative for malignancy & $\begin{array}{c}\text { Suspicions for } \\
\text { malignancy }\end{array}$ & Inadequate \\
\hline 00 & 85 & 00 & 1 \\
05 & 124 & 01 & 03 \\
04 & 42 & 00 & 01 \\
25 & 08 & 01 & 01 \\
01 & 00 & 02 & 00 \\
03 & 00 & 00 & 00 \\
01 & 01 & 00 & 00 \\
01 & 00 & 00 & 00 \\
\hline $40(12.90 \%)$ & $260(83.87 \%)$ & $04(01.29 \%)$ & $06(1.93 \%)$ \\
\hline
\end{tabular}

Out of 310 cases, 122 specimens were available for histopathological study.

Table II: Cytological and histopathological diagnosis $(n=122)$

\begin{tabular}{|c|c|c|c|c|c|c|c|c|c|c|}
\hline \multirow[b]{2}{*}{$\begin{array}{l}\text { S1. } \\
\text { No. }\end{array}$} & \multirow[b]{2}{*}{$\begin{array}{l}\text { Cytological } \\
\text { diagnosis }\end{array}$} & \multicolumn{9}{|c|}{ Histopathologic diagnosis } \\
\hline & & Total & F.A. & FCD & Malignancy & Inflamunatory & Galactocoele & $\begin{array}{c}\text { Duct } \\
\text { papilloma }\end{array}$ & $\begin{array}{l}\text { Benign } \\
\text { phylloides } \\
\text { tumour }\end{array}$ & $\begin{array}{c}\text { Old } \\
\text { hemorrhage }\end{array}$ \\
\hline 1. & $\begin{array}{l}\text { Benign fibroadenoma } \\
\text { (FA) }\end{array}$ & 76 & 73 & 02 & 00 & 00 & 0 & 0 & 1 & 0 \\
\hline 2. & $\begin{array}{l}\text { Fibrocystic disease } \\
\text { (FCD) }\end{array}$ & 23 & 2 & 21 & 00 & 00 & 0 & 0 & 0 & 0 \\
\hline 3. & $\begin{array}{l}\text { Fibrocystic disease } \\
\text { with atypia }\end{array}$ & 01 & 0 & 00 & 01 & 00 & 0 & 0 & 0 & 0 \\
\hline 4. & Inflammation & 02 & 0 & 0 & 00 & 02 & 0 & 0 & 0 & 0 \\
\hline 5. & Galactocoele & 01 & 0 & 0 & 00 & 00 & 01 & 0 & 0 & 0 \\
\hline 6. & Duct papilloma & 01 & 0 & 0 & 0 & 00 & 0 & 1 & 0 & 0 \\
\hline 7. & Unsatisfactory smear & 01 & 00 & 01 & 00 & 00 & 0 & 0 & 0 & 0 \\
\hline 8. & Old hemorrhage & 01 & 0 & 0 & 00 & 00 & 00 & 0 & $\theta$ & 01 \\
\hline 9. & Malignant & 14 & 0 & 0 & 14 & 00 & 00 & 0 & 0 & 0 \\
\hline \multirow[t]{2}{*}{10.} & $\begin{array}{l}\text { Suspicious for } \\
\text { malignancy }\end{array}$ & 02 & 0 & 01 & 01 & 00 & 00 & 0 & 0 & 0 \\
\hline & Grand Total & 122 & 75 & 25 & 16 & 02 & 01 & 01 & 01 & 01 \\
\hline
\end{tabular}

Table III:

\begin{tabular}{|c|c|c|c|c|c|c|c|c|c|}
\hline \multicolumn{9}{|c|}{ Benign } & \multirow{2}{*}{$\begin{array}{l}\text { Malignant } \\
\text { Duct cell } \\
\text { carcinomi }\end{array}$} \\
\hline $\begin{array}{l}\text { Age in } \\
\text { years }\end{array}$ & $\begin{array}{c}\text { Fibro } \\
\text { adenoma }\end{array}$ & $\begin{array}{c}\text { Fibrocystic } \\
\text { disease }\end{array}$ & $\begin{array}{c}\text { Fibrocystic } \\
\text { disease with } \\
\text { atypia }\end{array}$ & Galactocoele & $\begin{array}{c}\text { B. } \\
\text { phyllodes } \\
\text { tumour }\end{array}$ & Inflammatory & $\begin{array}{c}\text { Old } \\
\text { haemorrage }\end{array}$ & $\begin{array}{c}\text { Duct } \\
\text { papilloma }\end{array}$ & \\
\hline $11-20$ & 30 & 01 & 0 & 0 & 0 & 0 & 0 & 0 & 0 \\
\hline $21-30$ & 42 & 04 & 0 & 01 & 01 & 0 & 0 & 0 & 0 \\
\hline $31-40$ & 03 & 16 & 0 & 0 & 01 & 0 & 0 & 0 & 010 \\
\hline $41-50$ & 0 & 04 & 0 & 0 & 0 & 01 & 01 & 01 & 09 \\
\hline $51-60$ & 0 & 0 & 0 & 0 & 0 & 0 & 0 & 0 & 04 \\
\hline 61.70 & 0 & 0 & 0 & 0 & 0 & 0 & 0 & 0 & 02 \\
\hline $71-80$ & 0 & 0 & 0 & 0 & 0 & 0 & 0 & 0 & 0 \\
\hline 81.90 & 0 & 0 & 0 & 0 & 0 & 0 & 0 & 0 & 0 \\
\hline Total & 75 & 25 & 0 & 01 & 02 & 01. & 01 & 01 & 16 \\
\hline
\end{tabular}


Table-IV

\begin{tabular}{|l|l|l|l|l|}
\hline \multicolumn{1}{|c|}{ Authors } & \multicolumn{1}{|c|}{ Final diagnosis } & \multicolumn{1}{|c|}{$\begin{array}{c}\text { False positive } \\
\text { No, (\%) }\end{array}$} & \multicolumn{1}{|c|}{$\begin{array}{c}\text { False negative } \\
\text { No. (\%) }\end{array}$} & \multicolumn{1}{|c|}{$\begin{array}{c}\text { Accuracy } \\
\text { No. (\%) }\end{array}$} \\
\hline Present study & 122 & 01 & 01 & 98.36 \\
\hline Strawbridge et al & $\begin{array}{l}890(\mathrm{~T}) \\
279(\mathrm{M}) \\
611(\mathrm{~B})\end{array}$ & $27(3 \%)$ & $85(9.6 \%)$ & 47.00 \\
\hline Lannin et al $^{12}$ & $\begin{array}{l}100(\mathrm{~T}) \\
30(\mathrm{M}) \\
70(\mathrm{~B})\end{array}$ & 0 & $4(4.0)$ & 96.00 \\
\hline O'Neil et al & $\begin{array}{l}692(\mathrm{~T}) \\
495(\mathrm{M}) \\
197(\mathrm{~B})\end{array}$ & $44(6.0)$ & $13(1.9)$ & 92.00 \\
\hline
\end{tabular}

\section{Discussion}

It has already been established that fine needle aspiration cytology of breast lump is an easily performed out patient diagnostic method for determining the nature of the masses ${ }^{8}$. Results from his series also have confirmed a high efficiency comparable to series by Bjurstam and associates and in one by Schondarf ${ }^{10}$. Table IV shows the comparative evaluation of FNAC of present study with other.

In this study, the cytological reports were catagorized into four groups: positive for malignancy, negative for malignancy, suspicious for malignancy and unsatisfactory smeat.

In present series, there was one unsatisfactory smear, which on histologic examination proved negative for malignancy. In 122 cases, 75 cases were fibroadenoma (FA), 25 cases were fibrocystic disease. (FCD), 16 cases were malignant, 2 cases inflammatory, one case galactocoele, one benign phylloides tumour, one duct papilloma and one old haemorrhage. There were one false positive and one false negative result. There were two cases reported as suspicious for malignancy. Histopathologically one such case Was proved as malignant and the other one as FCD. Another cytological diagnosis of FCD with mild atypia was proved as duct cell carcinoma on histopathology.

From the present study and reviewed literature, it is evident that FNAC of the palpable breast lump is an accurate, highly sensitive method of diagnosing the breast lump. It is simple and time saving method, no anaesthesia is required and operative risk of surgieal biopsy could be avoided. It is cost effective and can be repeated as and when necessary.

In present series as the study group was small, percentage of accuracy was relatively high than other study mentioned in table no. IV.

There are some limitations to this procedure, for example, a malignant lesion smaller than $1 \mathrm{~cm}$ may be missed during aspiration resulting in false negative results. Lack of cellular pleomorphism often gives false negative diagnosis.

\section{Conclusion}

In conclusion, it may be said that FNA is a reliable tool for different diagnosis of breast lumps. It may be a conclusive diagnosis of a benign lesion. Histological confirmation may be indicated over FNA for prognostic reasons. 


\section{Acknowledgement}

It is our pleasure to give thanks to all doctors and staffs of the Department of Pathology, Dhaka Medical College for their active help and kind co-operation to perform this study.

\section{References}

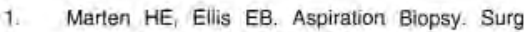
Gynae Obst 1934; 59: 578-587.

2. Stewart F W. The diagnosis of turnour by aspiration. Am J Path 1933; 9;801.

3. Goldwin J T. Aspiration biopsy, technique and application. Ann N Y Acad 1956; 63:1348

4. Edward DJ, Welkinson M D, Charlene M, et al. Aspiration cytology. Acta Cytologica1989; 33(5): $12-23$,

5. Wanebo HJ, Feldman PS, Wilhelm MC, et at. Fine needle aspiration Cytology in lieu of open biopsy in management of primary breast Cancer. Ann Surg 1984; 199:569-79.

6. Wilson $\mathrm{SL}$, Ehrmann RL. The cytologic diagnosis: Acta cylol 1978; 22: 470-75.

7. Sunders G, Laskra $Y$, Liboke J. Comparisen of needie aspiration cytologic diagnosis with excisional biopsy tissue diagnosis of palpable tumour of the breast in a community hospital. Surg Gynaє Obst 1991; 172;437-40.

8. Yelland $M_{1}$ Graham P A. Tralt H T, Ford R C, Coombes J C, Gazt NG. Diagnosing breast carcinoma in young women. BMJ 1991; 302:122. 25.

9. Schondorf H. Aspiration cylology of the breast, London. WB Saunders, 1977: 129-31.

10. Donald $A$, Lannin $M D$, Jan $F$, Silverman $D$, Cheryl walker RN, Walter J, Paries M. Cost elfectiveness of Fine needle biopsy of breast. Ann Surg 1986; 203(5): 45-51.

All correspondence to Hazara Khatun Assistant Protessor Department of Histopathology Rajshahi Medical College Raishail-6000, Bangladesh. 